idealismens scenografi' (s.12) begynder efterhånden at ligne antiretorikkens kunstmiddel: Den realistiske hårdhed, der som den eneste formulerer menneskets alvorlige situation og alene tør føre en 'ansvarlig politik'.

De fire forfatterskaber Jalving anvender, er blandt verdenshistoriens måske meste kendte for netop at bruge 'realismen' som et retorisk træk. Men den selviscenesættelse er Jalving desværre på ingen måde opmærksom på, og det gør hans begreb om politik historisk invariant. At politik blev grundlagt som en streng geometrisk videnskab i 1600-tallet, måtte der vel være bestemte historiske grunde til? Men skal vi derfor blot positivt overtage disse forudsætninger? Jalving taler om "den klassiske problematik mellem magt og ret, politik og moral' (s.10) - her er 'politik' blevet et proprium med faste spørgsmål og svar, der uden større problemer kan overføres fra det ene århundrede til det andet. Men de politiske begreber Jalving post festum betragter som realistens værktøjskasse, var vel også under deres etablering i 1600-tallet først udsat for en historisk fortætning og navngivning? Det medfører flere problemer: Fx taler Jalving med Hobbes som mundstykke om en hobbesiansk naturtilstand i vore dages internationale system - et forhold Hobbes stort set ikke så behov for at forholde sig til (s.75). Tilsvarende glemmes den formoderne karakter ved Machiavellis republikanske helhedstænkning, til fordel for helt at betragte ham som del af en moderne borgerlig tradition, der hyldes som 'realismen' (s.13).

Jalvings bog argumenterer for, "at vi ikke kan tale om alting" - og dermed overtager han altså også blindt realismens historiske bestræbelser på at 'sikkerhedsliggøre' og begrænse de politiske temaer, vi kan tillade os at debattere. Her må fantasien adskilles fra politikken, fordi realistens politiske rationalitet åbenbart som den eneste ikke er noget konstrukt! (s.154). Det fører mig til spørgsmålet om, hvem der egentlig skal bedrive denne illusionsløse politik: Genopliver Jalving gravens røster for at tale til regeringen, til en ræsonnerende offentlighed, til det verdenssamfund der benægtes at eksistere, eller til hvem? Spørgsmålet er også, om vi ikke netop som en folge af statssystemets historiske succes, kan tillade os at betragte realismen med en mindre nødvendighed i dag?

I det hele taget er der meget stof til eftertanke i Mikael Jalvings bog - især om hvor stor politisk afstand der faktisk kan være til nogle tekster, der ligger 400 år tilbage. Bortset fra nogle forstyrrende faktabokse det er svært at se meningen med, er Jalvings bog velformuleret og udstyret med stort engagement. Om ikke andet dokumenterer den, at den såkaldte afvikling af politikken ikke foregår uden kamp.

Casper Hartmann Dam

Vigtigt bidrag til forståelse af terrorismen 
Anne Sorensen og Steven L. B. Jensen (Red.): Terror-ismer, Den Iyske Historiker nr. 115, 2007, $140 \mathrm{kr}$.

Med Terror-ismer træder Den Jyske Historiker ind i feltet af utallige udgivelser, der har til hensigt at beskrive og analysere terrorismen for en stadigt uforstående offentlighed. Tidsskriftets bidrag er imidlertid på ingen måde uvæsentligt, og de forbehold jeg giver udtryk for i det følgende bør ikke skygge for, at udgivelsen varmt kan anbefales for alle, der har en interesse inden for feltet.

Som den lille bindestreg i titlen Terror-ismer synes at antyde, har udgivelsen fokus på terrorismen som ideologi. Denne formodning bekræftes til fulde af Anne Sørensen og Steven L. B. Jensens forord, der først og fremmest lægger vægt på terrorismens begrebshistorie fra 1789 til 9-11. Gennemgangen heraf er både læseværdig og absolut forbilledlig, men valget af denne tilgang afspejler også en mangel ved udgivelsen i sin helhed, ikke mindst $i$ betragtning af at Den Jyske Historiker udgør et af historievidenskabens flagskibe, nemlig fraværet af mere eksplicitte metodiske refleksioner over hvorledes terrorismen bør analyseres som fænomen. Terrorismens skikkelser $\mathrm{i}$ tre forskellige kontekster - Irland, Forbundsrepublikken og USA - gennemgås ganske vist enkeltvist, men hvorledes disse fremtrædelsesformer kan sammenlignes på tværs af konteksterne, og hvorledes de som enkeltfænomener bør sammenholdes med refleksionerne i Mikkel Thorups og Mats Fridlunds artikler, hvori terrorismen fremstilles $i$ et mere generelt perspektiv, kunne med fordel have været mere tydeligt udtrykt. Ydermere kan man sætte spørgsmålstegn ved om udvalget er helt bredt nok. I forordet understreges det, at vi for at forstå terrorismen må forstå dens kontinuitet, og bl.a. sætte spørgsmålstegn ved distinktionerne mellem 'gammel' og 'ny' terrorisme. For at illustrere mangelen ved de traditionelle distinktioner burde man derfor nok have inddraget i hvert fald én artikel, der analyserede terrorisme i en ikke-vestlig kontekst. Et bidrag om PFLP, FNL eller FARC ville således have styrket udgivelsens komparative tilsnit betragteligt.

Som titlen antyder, gennemgår Mikkel Thorup i sin artikel "Anarkister og partisaner - terroristiske figurer fra den irregulære krigs historie" hvorledes statens og statsordenens primære fjender er blevet opfattet af såvel staterne som af de aktører, der har været behæftet med disse prædikater. Den første centrale pointe er, at skønt at anarkisten som ordensomvaltende adskiller sig radikalt fra den ordensreformerende partisan, har disse to klassiske repræsentanter for statens negation både udgjort en fælles motor for statslige initiativer med henblik på at imødekomme enhver statsfjendtlig aktivitet og en fælles inspirationskilde for nyere modstandere af staten - som for eksempel Al Qaïda. Hvor Thorups gennemgang 
af denne udvikling er klart og tydeligt beskrevet, er han noget mere forbeholden, når det kommer til artiklens anden hovedpointe, at inspirationen fra såvel anarkisten som partisanen har medført et skisma i Al Qaïda mellem ambitionen om en abstrakt, universel omvæltning af verden som vi kender den, og forfølgelsen af konkrete, partikulære delmål. Thorup synes at hælde til, at inspirationen fra den anarkistiske og ikke-territoriale arv er så stærk i Al Qaïda, at dens terrorisme må siges at adskille sig radikalt fra terrorismen $i$ den anden halvdel af det 20. århundrede (med David Rapoports ord terrorismens anden og tredje bølge) i og med at den i langt højere grad var knyttet til partisanfiguren, til partikulære, nationale ambitioner. Det er en interessant men ikke uimodsagt pointe, og det ville have været styrket artiklen yderligere, hvis der var blevet levnet plads til en mere indgående diskussion mellem Thorup og forfatterne til forordet (der i højere grad understreger kontinuiteten mellem klassisk og moderne terrorisme) om netop dette spørgsmål.

Efter de mere generelle overvejelser i forordet og i Thorups artikel følger tre analyser af specifikke cases. Som et arketypisk eksempel på en etnisk-religiøs konflikt og på brugen af irregulære voldsmetoder fra både statens, dens tilhængeres og dens modstanderes side, er konflikten i Irland central for forståelsen af de problematikker som denne udgivelse, og terrorforskningen generelt, skal forholde sig til, og Michael Böss' beskrivelse af godt 100 års irsk historie i artiklen "Kampen om Irland - IRA og den irske stat" er god at blive klog af. Historien om Michael Collins og Eamon de Valera, om hvorledes sammenstødet mellem idealisme, pragmatisme og opportunisme skaber højest uhellige alliancer, er altid spændende, men artiklens egentlige styrke er den evne til at understrege hvorledes de religiøse, politiske og etniske skillelinjer ikke fra begyndelsen af var sammenfaldende. Det klare og indgående deskriptive fokus har helt klart sine fordele, men også sine ulemper. Når Böss eksempelvis med henvisning til Richard English påpeger at IRA's 'flyvende kolonner', en eufemisme for organisationens dødspatruljer under konflikten i 1920-21, kunne udføre deres attentater mod øvrighedspersoner og civile protestanter, fordi patruljerne opererede uden for deres eget lokalområde, så ville det have været interessant med en sammenligning til lignende studier af andre etniske konflikter, eksempelvis på Balkan i 1990erne, hvor bødlerne omvendt ofte skulle findes blandt naboer, arbejdskolleger og barndomsvenner.

I artiklen "Når terrorisme bliver historie - den vesttyske røde terrorismes efterliv" bekræfter Anne Sørensen endnu en gang sin position som RAF-forskningen ubestridte dronning herhjemme. Sørensen er inde $i$ sit stof og beskriver således på mesterlig vis, hvorledes den røde terror har bevæget sig fra statsfjende til mo- 
defænomen, og hvorledes en organisation, der i sin samtid blev betegnet som ideologisk umoden og eklektisk, i dag af selv dens argeste modstandere fremstilles som formålsmættet og konsistent i sammenligning med den islamiske terrorisme. Fra en ikke-faghistorikers synspunkt synes bidraget dog at lide af én afgørende svaghed, nemlig en forklaring på det, der ifølge overskriften er artiklens ærinde: Hvad betyder det, at et fænomen bliver historie? Hvorfor bliver én reception en rettesnor og en anden et vildspor? Findes der bagved receptionerne en historisk kerne, og hvilken betydning har denne kerne, når først tiden har lagt en diskursiv hinde af fortolkninger, gen- og modfortolkninger ovenpå det skete? Særligt diskussionen om eksistensen af en tysk Sonderweg ville være blevet styrket, hvis den var blevet suppleret med en mere indgående refleksion over hvad netop perceptionen af en sådan særstatus - uanset dens faktiske eksistens eller ej - betyder for opkomsten af sådanne grupper.

Lars Erslev Andersens artikel "Fra Christian Identity til Aryan Jihad - om amerikansk terrorismes baggrund i højreekstremisme" beskriver hvorledes terrorisme på amerikansk jord ikke er noget nyt fænomen, og hvorledes den ensidige fokus på islamisk terrorisme så at sige blotter de vestlige samfunds højre flanke. Erslev Andersen retter her fokus mod et væsentligt felt både i forhold til at forstå terrorismen generelt (at den ikke blot iklæder sig kommunismens røde eller islams grønne gevandter, men også kommer i en sort, højrerabiat, skikkelse), og han øger læserens forståelse af USAs meget vidtgående reaktioner på terrortruslen. Artiklen indeholder desuden et afgørende twist, i og med at den beskriver, hvorledes to for en umiddelbar betragtning helt og holdent modsatrettede bevægelser - den islamiske terrorisme, født i og næret af modstand mod vestlig dominans, og amerikansk højrenationalisme, funderet på troen om denne overhøjheds historiske, racemæssige og religiøse berettigelse - kan mødes i en fælles modstand mod Forbundsregeringens politik. Det er således Erslev Andersens pointe, at rabiat islam og rabiat højrenationalisme ikke blot, som blandt andre John Gray har påpeget, er forbundne gennem en fælles jakobinsk arv, men helt konkret og eksplicit vedkender sig et værdifællesskab. I lighed med Mikkel Thorup synes Erslev Andersen at lægge vægt på forandringen frem for kontinuiteten $i$ sin perception af terrorismens historie. Han understreger således betydningen af landbrugskrisen i Midtvesten i 1980erne i forhold til at forstå terrorismens rødder. Ulempen ved en sådan entydig årsagsforklaring er, at den let kommer til at skygge for det faktum, at moderne amerikansk højrenationalisme netop er en moderne variant at et klassisk tema $\mathrm{i}$ amerikansk identitet. En inddragelse af dette aspekt ville have kunnet bidrage til en forståelse af det, Erslev 
Andersen kommenterer, men lader stå uforklaret, hvorfor den europæiske højrenationalisme i mindre grad end sin amerikanske modpart har skabt basis for en samlende anti-parlamentarisk bevægelse; eftersom det mest signifikante træk ved den europæiske højrebølge er at den betjener sig af og bekender sig til demokratiets organer.

Mats Fridlund afslutter nummerets tema med en mere generel artikel "Helvetsmaskinerna - Terrorismens teknologi från giljotinen till videokameran", hvori han fra et teknologihistorisk perspektiv betoner betydningen af terrorens midler for etableringen af dens mål. Artiklen er i høj grad modelleret som et opgør med Rapoports kulturhistoriske og, ifølge Fridlund, essentialistiske tilgang. I stedet for som Rapoport at pointere de bagvedliggende motiver, de være sig politiske, nationalistiske eller religiøse som terrorens drivkraft, søger Fridlund at vise hvorledes terrorens våben fra de judæiske sikarieres knive til de irakiske henrettelsespeletoners hjemmevideoer ikke alene interagerer med terrorens hensigter men virker direkte determinerende herfor. Opgøret virker desto mere overbevisende fordi det foretages på Rapoports egne præmisser, i og med at det struktureres $i$ henhold til dennes inddeling af terrorismens historie. Uanset om man er enig med Rapoport eller Fridlund, udgør artiklen et befriende bud på en nylæsning af terroren som fænomen, et bud som åbner for helt nye perspektiver inden for dette til tider fastlåste og redundante forskningsfelt. Sammen med dette gør artiklens klare målsætning og overbevisende argumentation den da også til det bedste bidrag i nummeret, hvilket - den i øvrigt høje standard taget i betragtning - slet ikke siger så lidt.

Morten Brander

\section{Den indre religionskrig}

Jobn Pedersen: Tvivl og tolerance.

Et skrift om Pierre Bayle, Museum Tusculanums Forlag, 2006, 111 sider, 148 kr.

Det er ikke meget der er skrevet om Pierre Bayle herhjemme (1647-1706), og skal man tro John Pedersen er meget af det skrevne ikke særligt meget værd. Dette er sådan set grundtenoren i Pedersens lille 'skrift' om Pierre Bayle, der vel frem for alt er kendt som forfatter til værket Dictionnaire historique et critique (Historisk og kritisk ordbog) fra 1696-97 - et værk der begyndte som et modskrift til eksisterende ordbogsartikler, men som med sine mange kommentarer og noter hurtigt udviklede sig til et selvstændigt værk. Ofte befandt meget af det virkeligt kritiske stof sig i de mange tusinde noter og på dette punkt dannede Bayle tydeligvis skole for Diderot og d'Alemberts senere encyklopædi. 